\title{
Beszámoló a Regional Studies Association éves európai konferenciájáról (Tampere, Finnország, 2013. május 5-8.)
}

\section{Report on the annual European conference of the Regional Studies Association}

BAJMÓCY ZOLTÁN, LUX GÁBOR

A Regional Studies Association (RSA) szokásos éves európai konferenciáját idén Finnországban, a Tamperei Egyetem társszervezésével rendezte meg. A társaság a tavalyi évtől kezdődően az európai mellett egy „globális” konferenciát is szervez.

A tamperei konferencia közel 400 résztvevőt vonzott. A plenáris előadások mellett 85 szekcióban vitatták meg a résztvevők a regionális tudomány aktuális kérdéseit. A rendezvény idén is megőrizte a korábbiakhoz hasonló interdiszciplináris jellégét. A European Regional Science Association (ERSA) konferenciáival ellentétben, ahol túlsúlyban vannak a modellező és kifejezetten közgazdaságtani jellegű előadások, az RSA-n az előbbivel azonos vagy még nagyobb súllyal vannak jelen a gazdaságföldrajzi, szociológiai és politikatudományi hátterű szerzők. A matematikai-statisztikai modellezés mellett számos előadásban a kvalitatív társadalomtudományi kutatási módszerek dominálnak.

Mindez jól megmutatkozott abban is, hogy az idei legjobb előadás díját Martina Fuchsnak (Kölni Egyetem, Németország) ítélték egy kifejezetten szociológiai gyökerü és alapvetően elméleti munkáért: Knowledge and patterns of interpretation: Two complementary approaches for a better understanding of mental constructions in economic geography. A konferencia legjobb fiatal előadójának járó elismerést Viktorija Šipilova (Daugavpils Egyetem, Lettország) vehette át: Aspect of structural changes in manufacturing: Search of new approaches for classifying the European Union member countries címü munkájáért.

A konferencia mottója idén a következő volt: Alakítani és alakulni: a regionális fejlődés jövőbeni dinamikája. A három plenáris szekció az EU regionális politikája, a regionális és helyi kormányzás, valamint a tudásgazdaság szereplői (ágensei) témák köré szerveződtek.

Jelentős figyelmet szentelt a konferencia az európai válság területi következményeinek. Michael Parkinson (igazgató, European Institute for Urban Affairs) előadásában a szélsőségesen fővároscentrikussá váló területi fejlődés kockázataira és

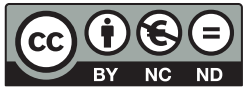


az európai városhálózat második szintjében rejtőző lehetőségekre hívta fel a figyelmet. Míg a válság előtti évtizedben több országban a nemzeti központokon kívüli nagyvárosok mutatták a legerőteljesebb növekedést, a posztszocialista térségben már ekkor is a fövárosok előretörésének lehettünk tanúi, azóta pedig a különbségek még súlyosabb kiéleződését tapasztalhatjuk. Mint hangsúlyozta, a kormányzati teljesítmény kulcsszerepet játszik a válságkezelésben, ez a tényező pedig robusztus összefüggést mutat a decentralizáció mértékével, a területi különbségek mérséklése iránti elkötelezettséggel.

Az európai regionális politika változásairól és a 2014-2020-as programozási időszakról nyújtott összefoglalót John Bachtler (igazgató, European Policies Research Centre, University of Strathclyde). A kohéziós politika jelentős kritikákat kapott, mert nem illeszkedett az EU közös céljaihoz és területi kapcsolódásait is elveszítette; így az új tervidőszakban nagyobb összhangot próbálnak elérni az Európa 2020 program célkitűzéseivel, és általánossá válik a helyközpontú (place-based) szemlélet alkalmazása. Várhatóan a „kemény” infrastruktúra felől elmozdulást tapasztalunk az emberi erőforrások és az oktatás, valamint az esélyegyenlőség felé. A regionális politika megvalósulásában fokozottabb figyelmet kap az adminisztrációs kapacitások fejlesztése, az abszorpció és a jelenleginél erősebb monitoring.

A következő előadásban Pascal Boijmans (csoportvezető, Európai Bizottság DG REGIO Competence Centre Administrative Capacity Building) szintén az adminisztráció problémáit hangsúlyozta: az igazgatási képesség különbségei meghatározó eltéréseket generálnak a kohéziós politika hatékonyságában is. Míg egyes tagállamokban az üzleti szféra elszívó ereje tizedelte meg a döntéshozók körét, máshol a gyenge szabályozás, a közbeszerzési szabályok szűk keresztmetszetei vagy hiányzó intézmények rontják az igazgatás hatékonyságát. A problémát érzékelve a bizottság felállította kompetenciaközpontját, amely kidolgozott szervezeti megoldásokkal, a jó gyakorlat átadásával segíti a tagállamokat. (E sorok íróját az előadás alatt furcsa déjà vu érzés fogta el, pedig még nem is élt Brezsnyev alatt - L.G.)

A pénzpiacok földrajzát elemezve Dariusz Wójcik (St. Peter's College, University of Oxford) rámutatott, hogy a globális pénzmozgásokban a világvárosok és offshore területek mellett jogosan nevezhetjük az áramlások harmadik pólusát „a fennmaradó résznek": a befektetéskezelő szervezetek többsége 30-60 offshore területen működik, amelyeket a fejlett pénzügyi szolgáltatások kapcsolnak össze. További koncentrációt jelent, hogy a globálisan meghatározó 43 ezer transznacionális vállalat megtermelt hozzáadott értékének 40\%-át összesen 147 irányító szervezet osztja újra, s ezek mintegy háromnegyede pénzügyi szervezet. Megfigyelhető, hogy már a nagyvállalati központok elhelyezkedésében sem a termelés, hanem a pénzügy földrajza játszik vezérlő szerepet; az irányítás a pénzpiacok megacentrumaiba kerül át.

A regionális tudományban végbement intézményi fordulat következményeiről szólva John Tomaney (Bartlett School of Planning, University College 
London) felhívta rá a figyelmet, hogy az új paradigma egyben új ortodoxiává is vált: az állam konstruktív felfogását és a társadalmi intézmények jelentőségét hangsúlyozó irányvonal egyben a városrégiók szerepének abszolutizálásához is vezetett. Miközben a területi különbségek kialakulása természetes jelenség, a közpolitika a gazdasági hatékonyság nevében egyre inkább az erőforrás-koncentrációt szorgalmazza, cselekvésében pedig az elit nevében és a demokrácia félreállításával lép fel. A föáramban a többszintű kormányzásra való hivatkozás gyakran üres szólam, mindenre jó „varázsszer” marad. Az előadó hangsúlyozta: nem az intézmények ereje, hanem jó működésük a lényeges (hiszen az erős szervezetek önfenntartó reflexei rossz megoldások konzerválásához is vezethetnek); a jó intézmények kialakítása pedig szinte mindig lassú folyamat, vagyis az intézményi megoldások nem gyorssegélyként, hanem csak hosszú távon segíthetik a kormányzati és területi problémák megoldását.

A 2010-ben Pécsett megrendezett konferenciát leszámítva a magyar előadók száma relatíve alacsony az RSA rendezvényein; jellemzően öt és tíz fó között mozog. Idén sem volt ez másként: tíz hazai kolléga vett részt a konferencián nyolc előadással:

- Bajmócy Zoltán (Szegedi Tudományegyetem) és Elekes Zoltán (Szegedi Tudományegyetem): Innovation performance and regional success - Insights from the capability approach.

- Benedek József (Miskolci Egyetem): Paths of the territorial catching-up process on the periphery, with special focus on the Visegrad countries (távol maradó társszerző: Kocziszky György).

- Forman Balázs (Budapesti Corvinus Egyetem): Dependencies in spatial financial markets. Dependent relations in periphery of the European Union.

- Horváth Sarolta (Szegedi Tudományegyetem): Measurement approaches of the competitiveness of city regions.

- Lengyel Balázs (International Business School Budapest): Foreign firms and the potential synergy in regional innovation systems: The case of Hungary (távol maradó társszerző: Loet Leydesdorff).

- Lengyel Imre (Szegedi Tudományegyetem): Hungarian city-regions in transition: Agglomeration economies in the dual economy.

- Lukovics Miklós (Szegedi Tudományegyetem): Surveying the clustering opportunities of SMEs in the Hungarian-Romanian cross border region (távol maradó társszerzők: Imreh Szabolcs és Patik Réka).

- Lux Gábor (MTA KRTK RKI Pécs): Establishing innovative development cooperation on the periphery: Experiences from Hungarian city-regions.

- Vas Zsófia (Szegedi Tudományegyetem): Innovation and knowledge intensity in the less developed Southern Great Plain region of Hungary.

A magyar előadások viszonylag alacsony száma és a hazai tagság hektikus volta vélhetően financiális okokkal is magyarázható. Igen gyakori, hogy egyegy kolléga az adott évi konferencia miatt taggá válik, de tagságát a következő 
évben már nem újítja meg. Mindez azért is sajnálatos, mert a szervezet számos lehetőséget kínál tagjai számára.

Amellett, hogy a tagoknak járnak a Regional Studies, a Spatial Economic Analysis és a most indult Territory, Politics, Governance folyóiratok, a szervezet számos egyéb lehetőséget is kínál. Az igen jól működő hírlevélrendszer mellett az RSA komoly forrásokkal rendelkezik tagjai ötleteinek támogatására. Pályázni lehet nemzetközi hálózatok felállítására és működtetésére egy-egy kutatási téma mentén, továbbá konferenciák, workshopok szervezésére. A Regions címü magazin pedig kiváló fórumot kínál egy-egy ötlet vagy akár egy kutatócsoport bemutatására.

Az RSA az elmúlt időszakban kiemelten támogatja a pályájuk elején lévő kutatókat. Számukra konferencia-részvételi támogatást tesznek elérhetővé, illetve minden évben megrendezik az Early career konferenciát. A Regional Insights magazin is kifejezetten a fiatal kutatókra fókuszál. A lap szerkesztői a fiatal szerzőkkel együtt dolgozva, rendszeresen konzultálva juttatják el az ötletet a publikációig. Az elmúlt években külön a fiatal kutatókat segítő szekciókat is szerveztek az RSA-konferenciákon (pl. publikációs tippek, prezentációs tippek), amelynek legfontosabb tapasztalatai később a Regional Insights különszámaiban jelentek meg.

A szervezet idén decemberben Los Angelesben, jövő áprilisban Brazíliában tartja globális konferenciáját, az európait pedig jövő júniusban Törökországban (İzmirben). 


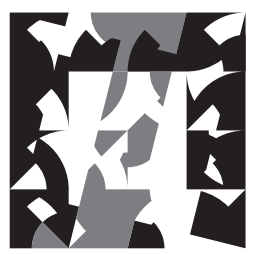

TÉR ÉS TÁRSADALOM | SPACE AND SOCIETY 